\title{
PENGARUH PERBEDAAN STRATEGI PEMBELAJARAN DAN GAYA BELAJAR TERHADAP KEMAMPUAN MEMBACA BAHASA INDONESIA
}

\author{
Dewi Yuliati ${ }^{1}$ dan Hamonangan Tambunan ${ }^{2}$ \\ SMP Dharma Pancasila Medan ${ }^{1}$ dan Universitas Negeri Medan ${ }^{2}$ \\ dewiyuliati@yahoo.com ${ }^{l}$
}

\begin{abstract}
Abstrak: Penelitian ini bertujuan untuk mengetahui: (1) hasil belajar Bahasa Indonesia siswa yang melalui proses pembelajaran pemahaman bacaan dengan strategi pemahaman bacaan Directed Reading Thinking Activity (DRTA) dan strategi pembelajaran Known-Want to know-Learned (KWL), (2) hasil belajar Bahasa Indonesia siswa yang memiliki kecendrungan gaya belajar visual, gaya belajar auditori dan gaya belajar kinestetik, (3) interaksi antara strategi pemahaman bacaan dan kecendrungan gaya belajar terhadap hasil belajar Bahasa Indonesia. Metode penelitian dalam penelitian ini adalah kuasi eksperimen dengan desain faktorial $2 \times 3$, sedangkan teknik analisis data menggunakan ANAVA dua jalur pada taraf signifikan $\alpha=0,05$. Hasil penelitian diperoleh: (1) hasil belajar bahasa Indonesia siswa yang diajar dengan menggunakan strategi pemahaman bacaan DRTA berbeda dibandingkan dengan hasil belajar bahasa Indonesia siswa yang diajar dengan menggunakan strategi pemahaman bacaan KWL, (2) Hasil belajar siswa yang memiliki kecendrungan gaya belajar visual berbeda dibandingkan siswa yang memiliki kecendrungan gaya belajar auditori dan kinestetik, dan (3) terdapat interaksi antara penggunaan strategi pemahaman bacaan dan kecendrungan gaya belajar siswa terhadap hasil belajar bahasa Indonesia siswa.
\end{abstract}

Kata Kunci: strategi pembelajaran, gaya belajar, kemampuan membaca bahasa indonesia

Abstract: This study aims to determine: (1) the learning outcomes Indonesian students through the learning process of reading comprehension strategies reading comprehension Directed Reading Thinking Activity (DRTA) and learning strategies Known-Want to know-Learned (KWL), (2) Indonesian learning outcomes of students who have a tendency visual learning styles, learning styles auditory and kinesthetic learning styles, (3) the interaction between reading comprehension strategies and learning styles tendency towards learning outcomes Indonesian. The research method in this study is a quasi experimental factorial design $2 \times 3$, whereas the data analysis techniques using ANOVA two lines at significant level $\alpha=0.05$. The results were obtained: (1) the learning outcomes Indonesian students who are taught by using strategies of reading comprehension DRTA different than the learning outcomes of Indonesian students who are taught by using strategies reading comprehension $K W L$, (2) the results of student learning has a tendency visual learning style is different compared to students who have a tendency auditory and kinesthetic learning styles, and (3) there is interaction between the use of reading comprehension strategies and learning styles of students 'tendency to Indonesian students' learning outcomes.

Keywords: learning strategy, learning style, ability to read

\section{PENDAHULUAN}

Banyak faktor yang menyebabkan rendahnya hasil belajar yang diperoleh siswa dalam pembelajaran, antara lain sebagaimana yang diungkapkan oleh Reigeluth dan Merril yang disitasi oleh Salamun (2009) bahwa klasifikasi variabel pembelajaran meliputi (1) kondisi pembelajaran, (2) metode pembelajaran, dan (3) hasil pembelajaran. Semua variabel tersebut memiliki ketergantungan satu sama lain dan tidak dapat berdiri sendiri dalam memberhasilkan pembelajaran. Proses pembelajaran akan semakin efektif apabila strategi pembelajaran yang dipergunakan sesuai dengan karakteristik siswa dan tipe isi bidang studi yang diajarkan.

Kondisi pembelajaran Bahasa Indonesia diarahkan untuk meningkatkan kemampuan siswa berkomunikasi dalam bahasa Indonesia, baik secara lisan maupun tulisan. Berdasarkan hal tersebut maka mata pelajaran Bahasa dan Sastra Indonesia merupakan 
program untuk mengembangkan pengetahuan, kemampuan berbahasa dan sikap positif terhadap bahasa Indonesia. Aspek pembelajaran Bahasa dan Sastra Indonesia terdiri atas (1) kemampuan berbahasa Indonesia yaitu mendengarkan, berbicara, membaca, dan menulis, (2) bersastra baik, sastra lisan maupun sastra tulis. Kedua aspek ini (berbahasa dan bersastra) tidak memiliki perbedaan di dalam pelaksanaan. Materi yang berupa sastra lisan dipelajari dengan cara mengapresiasinya secara lisan yaitu didengarkan dan dibicarakan atau dibahas secara lisan dan tertulis. Materi yang berupa sastra tulis diapresiasi dengan cara dibaca dan dibahas secara tertulis atau secara lisan. Dengan demikian pada hakikatnya belajar bahasa Indonesia adalah belajar berkomunikasi, mengungkapkan ide, pikiran, perasaan, pengalaman, dan pendapat secara lisan dan tertulis (Chandra, 2010).

Strategi pembelajaran yang berorientasi pada KBK yang selama ini digunakan adalah salah satu dari strategi yang ada saat ini. Menurut Willis (2010: 45), aktifitas yang dapat memaksimalkan sebagai penanaman memori adalah dimana siswa menggunakan alat bantu grafis dan kegiatan-kegiatan lain seperti KWL. Ketika siswa menghubungkan informasi baru dengan pengetahuan serupa yang tersimpan di dalam KWL, maka "pancingan" ini akan meningkatkan keterbiasaan sehingga akan meningkatkan ingatan. Strategi KWL memberikan peran aktif siswa sebelum, saat dan sesudah membaca. Ketika siswa menghubungkan informasi baru dengan pengetahuan serupa yang tersimpan di dalam KWL maka "pancingan" ini akan meningkatkan ingatan.

Sedangkan menurut penelitian Melvita (2009:10) salah satu strategi membaca yang dapat memaksimalkan belajar siswa dan berorientasi pada siswa adalah strategi DRTA. Strategi DRTA memberikan kebebasan dan suatu peran aktif pada siswa dengan cara menarik minat dan perhatian mereka dengan memaparkan kepada siswa tujuan membaca sebelum kegiatan membaca dimulai. Menurut penelitian Melvita, siswa yang diajar dengan menggunakan strategi DRTA memiliki hasil belajar bahasa Inggris yang lebih tinggi dibandingkan dengan menggunakan strategi KWL. Selain itu Siswa dengan kecendrungan gaya belajar auditori memiliki hasil belajar bahasa Inggris lebih tinggi dibandingkan dengan siswa yang memiliki kecendrungan gaya belajar visual dan kinestetik.
Membaca tidak hanya sekedar mengingat (menghafal) namun juga memahami apa yang ditulis, adanya interaksi antara teks dan pembaca (McNeil, 2002:16). Seringkali membaca khususnya dalam bahasa Indonesia dianggap sebagai hal yang sangat mudah bagi siswa sekolah menengah pertama, namun pada kenyataannya ketika dihadapkan pada tes bahasa Indonesia dalam memahami bacaan, siswa mendapat hasil yang rendah. Hal ini terbukti pada rata-rata hasil ujian nasional bahasa Indonesia tahun ajaran 2010 lalu. Oleh sebab itu guru sebagai pendidik perlu membantu siswa dalam mengatasi masalah ini dengan mencari strategi yang dapat membantu siswa dalam memahami bacaan sehingga siswa dapat menemukan makna pada bacaan, mampu mengaitkan informasi yang telah ada dan pengetahuan baru yang didapatnya dan lain sebagainya. Strategi yang dipilih juga perlu mempertimbangkan faktor yang berasal dari siswa, dimana salah satunya adalah gaya belajar siswa agar proses pembelajaran dapat berjalan dengan efektif. Oleh karena itu perlu dilakukan penelitian mengenai pengaruh strategi pembelajaran dan gaya belajar terhadap hasil belajar bahasa Indonesia siswa sekolah menengah pertama.

Dalam memandang proses belajar, Bruner seperti yang disitasi oleh Budianingsih (2005:41) dengan teorinya yang disebut free discovery learning, dikatakan bahwa proses belajar akan berjalan dengan baik dan kreatif jika guru memberikan kesempatan kepada siswa untuk menemukan konsep, teori, aturan, atau pemahaman melalui contoh-contoh yang ia jumpai dalam kehidupannya. Sedangkan Piaget seperti yang disitasi oleh Budianingsih (2005:41) menyatakan bahwa perkembangan kognitif sangat berpengaruh terhadap perkembangan bahasa seseorang, maka Bruner menyatakan bahwa perkembangan bahasa besar pengaruhnya terhadap perkembangan kognitif. Adapun langkah-langkah pembelajaran menurut Bruner seperti yang disitasi oleh Budianingsih (2005:50) adalah sebagai berikut: (1) menentukan tujuan pembelajaran, (2) melakukan identifikasi karakteristik siswa (kemampuan awal, minat, gaya belajar dan sebagainya), (3) memilih materi pelajaran, (4) menentukan topik-topik yang dapat dipelajari siswa secara indukstif (dari contoh-contoh ke generalisasi, (5) mengembangkan bahan-bahan belajar yang berupa contoh-contoh, ilustrasi, tugas dan sebagainya untuk dipelajari siswa, (6) mengatur topik-topik pelajaran dari yang 
sederhana ke kompleks, dari yang konkret ke abstrak, atau dari tahap enaktif, ikonik sampai ke simbolik, (7) melakukan penilaian proses dan hasil belajar siswa.

Bloom seperti yang disitasi oleh Hamid (2009, 118-120) telah mengklasifikasikan hasil pembelajaran menjadi tiga yakni kognitif, afektif dan psikomotor. Kognitif adalah ranah yang menaruh perhatian pada pengembangan kapabilitas dan keterampilam intelektual. Afektif adalah ranah yang berkaitan dengan pengembangan perasaan, sikap, nilai dan emosi. Psikomotor adalah ranah yang berkaitan dengan kegiatan-kegiatan manipulator atau keterampilan motorik. Lebih lanjut, Anderson dan Krathwohl (2001:67-68) mengklasifikasikan dimensi taksonomi menjadi dua dimensi yaitu dimensi proses kognitif dan pengetahuan. Dimensi proses kognitif dibagi menjadi enam dan tiap-tiap klasifikasi dikembangkan lagi menjadi bagian-bagian klasifikasi yang lebih khusus. Semua klasifikasi diurut secara hirarkis dari yang paling sederhana (tingkat ingatan) sampai yang paling kompleks (tingkat kreasi).

Mata pelajaran Bahasa dan Sastra Indonesia merupakan program untuk mengembangkan pengetahuan, kemampuan berbahasa dan sikap positif terhadap bahasa Indonesia. Aspek pembelajaran Bahasa dan Sastra Indonesia terdiri atas (1) kemampuan berbahasa Indonesia yaitu mendengarkan, berbicara, membaca, dan menulis, (2) bersastra baik, sastra lisan maupun sastra tulis. Kedua aspek ini (berbahasa dan bersastra) tidak memiliki perbedaan di dalam pelaksanaan. Jika dilihat dari tujuan mata pelajaran Bahasa Indonesia dengan dimensi proses kognitif dan dimensi pengetahuan maka siswa belajar untuk bisa memahami informasi yang disampaikan penulis ataupun orang lain melalui bacaan, tulisan, dan perkataan. Dalam penelitian ini salah satu tujuan mata pelajaran bahasa Indonesia yang akan diteliti dibatasi pada siswa dapat memahami ragam teks non sastra dengan berbagai cara membaca.

Pemahaman terhadap bahasa tidak bisa dilepaskan dari kegiatan membaca, karena membaca merupakan langkah awal dalam memahami karya sastra (Kurniawan, 2009:52). Dengan membaca, maka prapemahaman (pemahaman awal pembaca setelah melakukan pembacaan) pembaca terhadap makna karya sastra dapat terjadi. Dalam prapemahaman ini, sebenarnya interpretasi pembaca atas karya sastra sudah terjadi sekalipun masih bersifat permukaan (impresi). Sastra sendiri adalah suatu produk budaya manusia yang imajinatif, mempunyai nilai estetis dan disampaikan dengan media bahasa. Membaca merupakan kemampuan yang kompleks. Membaca bukan hanya kegiatan memandangi lambang-lambang tertulis semata, tetapi berupaya mengubah lambang-lambang yang dilihatnya itu menjadi lambang-lambang yang bermakna baginya.

Ahli membaca Steve Stahl (2002) sebagaimana disitasi oleh Santrock (2007:420) percaya bawa tujuan instruksi membaca seharusnya dapat membantu murid untuk: (a) mengenali kata secara otomatis, (b) memahami teks, (c) termotivasi untuk membaca dan mengapresiasi membaca. Tujuan-tujuan tersebut saling terkait satu sama lain. Dalam usaha memperoleh pemahaman terhadap teks, pembaca (siswa) menggunakan strategi tertentu. Pemilihan strategi berkaitan erat dengan faktorfaktor yang terlibat dalam pemahaman, yakni pembaca teks dan konteks. Strategi pemahaman bacaan pada dasarnya menggambarkan bagaimana pembaca memproses bacaan sehingga ia memperoleh pemahaman terhadap bacaan tersebut. Hakekat pemahaman sendiri menurut Thorndike sebagaimana disitasi oleh McNeil (1992:16) pemerolehan pandangan dan manipulasi pandangan. Pemahaman berorientasi proses yang melibatkan aktivitas mental pembaca ketika berinteraksi dengan teks tertulis, pengukuran dilakukan dengan meminta pembaca menjawab pertanyaan. Dengan kata lain, memahami bacaan dapat didefinisikan sebagai kemampuan

Menurut Dick and Carey seperti yang disitasi oleh Atwi (2001:165) dikatakan bahwa suatu strategi instruksional menjelaskan komponen-komponen umum dari suatu set bahan instruksional dan prosedur-prosedur yang akan digunakan bersama bahan-bahan tersebut untuk menghasilkan hasil belajar tertentu pada siswa. Disebutkan juga lima komponen umum dari strategi instruksional, yaitu: (a) kegiatan pra instruksional, (b) penyajian informasi, (c) partisipasi siswa, (d) tes, (e) tindak lanjut. Kelima komponen tersebut bukanlah satusatunya rumusan strategi instruksional.

Strategi Pembelajaran Bahasa Indonesia berisi segala sesuatu yang dapat digunakan dalam menyusun rencana pembelajaran bahasa Indonesia secara cermat yang mengacu pada tujuan pembelajaran. Penyusunan strategi pembelajaran bahasa dan sastra Indonesia berpedoman pada kurikulum sekolah (SMP dan SMA) yang berlaku. Strategi 
pembelajaran dapat diartikan sebagai perencanaan yang berisi tentang rangkaian kegiatan yang didesain untuk mencapai tujuan pendidikan tertentu. Ada dua hal yang patut dicermati dari pengertian di atas (Maisah dan Yamin, 2009:135): (1) strategi pembelajaran merupakan rencana tindakan (rencana kegiatan) termasuk penggunaan metode dan pemanfaatan berbagai sumber daya atau kekuatan dalam pembelajaran. Ini berarti penyusunan suatu strategi baru sampai pada proses penyusunan rencana kerja belum sampai pada tindakan, (2) strategi pembelajaran disusun untuk mencapai tujuan tertentu. Artinya, arah dari semua keputusan penyusunan strategi adalah pencapaian tujuan.

Menurut Muchlish dan Oka (2010: 44)

bahasa Indonesia mempunyai ciri-ciri umum dan kaidah-kaidah pokok tertentu yang membedakannya dengan bahasa-bahasa lainnya di dunia ini, baik bahasa asing maupun bahasa daerah. Ciri-ciri umum dan kaidah-kaidah pokok yang dimaksud adalah antara lain sebagai berikut: (a) bahasa Indonesia tidak mengenal perubahan bentuk kata untuk menyatakan jenis kelamin, (b) bahasa Indonesia mempergunakan kata tertentu untuk menunjukkan jamak, (c) bahasa Indonesia tidak mengenal perubahan bentuk kata untuk menyatakan waktu, (d) susunan kelompok kata dalam bahasa Indonesia biasanya mempergunakan D-M (hukum DiterangkanMenerangkan) yaitu kata yang diterangkan (D) di muka yang menerangkan (M), (e) bahasa Indonesia juga mengenal lafal baku, yaitu lafal yang tidak

Strategi diperlukan untuk mencapai hasil belajar yang optimal. Menurut Maisah dan Yamin, (2009:220) penilaian dilakukan untuk menentukan apakah peserta didik telah berhasil menguasai suatu kompetensi yang mengacu pada indikator atau tidak. Penilaian dilakukan pada waktu pembelajaran atau setelah pembelajaran berlangsung. Sebuah indikator dapat dijaring dengan beberapa soal/tugas. Penilaian yang dimaksud dapat ditentukan dalam bentuk angka-angka atau nilai yang diberikan kepada siswa setelah menjalani proses pembelajaran. Biasanya diukur dengan menggunakan tes formatif atau tes sumatif.

Strategi exposition bahan pelajaran disajikan kepada siswa dalam bentuk jadi dan siswa dituntut untuk menguasai bahan tersebut. Dalam hal ini guru berfungsi sebagai penyampai informasi. Salah satu hal yang dapat meningkatkan kemampuan pemahaman membaca siswa adalah dengan menggali pengetahuan siswa tentang tema yang diajarkan. Strategi pembelajaran KWL berlandaskan pada bahan pelajaran dalam bentuk jadi yang harus dikuasai siswa. Dalam menguasai teks, siswa dapat berinteraksi dengan teman sekelompoknya. Bahan bacaan yang disajikan guru dalam kegiatan pembelajaran bahasa Indonesia umumnya adalah bahan bentuk jadi yang terdapat dalam buku pegangan/buku paket atau bahan bacaan yang terdapat dalam LKS (Lembar Kerja Siswa). Kegiatan siswa sebelum membaca teks bacaan dalam bentuk jadi adalah mendengarkan instruksi guru, pertanyaan guru dijawab dan melaksanakan tugas berdasarkan langkah-langkah yang diinstruksikan guru.

KWL adalah singkatan dari Know (yang diketahui), What to Know (yang ingin di ketahui), dan Learned (yang di peroleh). Ogle seperti yang disitasi oleh Buehl (1995: 107) menyatakan bahwa format KWL adalah suatu cara yang tepat untuk membantu siswa berpartisipasi aktif dalam membaca tentang apa yang sedang mereka pelajari dalam ruang lingkup tema. Metode pengajaran melalui teknik KWL akan lebih etektif dan suasana belajar akan lebih menyenangkan apabila diikuti dengan permainan bahasa. Permainan bahasa ini harus sesuai dengan ruang lingkup tema dan level siswa. Strategi instruksional KWL dapat dilihat pada Lampiran 1.

KWL menurut Ogle adalah strategi pemahaman membaca yang digunakan untuk menuntun siswa melalui teks bacaan. Kegiatan ini dimulai dengan siswa diberi kesempatan untuk betukar pikiran terlebih dahulu mengenai apa yang mereka ketahui (Know) tentang topik bacaan tersebut. Informasi ini akan disimpan di kolom K pada bagan KWL. Siswa kemudian membuat daftar pertanyaan mengenai apa yang ingin mereka ketahui (Want to Know) mengenai topik tersebut. Daftar pertanyaan ini dibuat di kolom $(W)$ pada bagan. Selama atau setelah membaca, siswa menjawab daftar pertanyaan yang telah dibuat di kolom $W$. Informasi baru yang diketahui ini dibuat di kolom L (Learned) pada bagan KWL.

Strategi KWL mempunyai beberapa tujuan, yaitu: (a) mengidentifikasi pengetahuan siswa mengenai topik bacaan, (b) menentukan tujuan dari membaca, (c) membantu siswa untuk memonitor pemahaman mereka, (d) mengijinkan siswa untuk menilai pemahaman mereka terhadap bacaan, (e) menyediakan kesempatan bagi siswa untuk mengembangkan pemikiran mereka di luar bacaan. Teori tersebut 
suatu teknik membaca kritis dimana pembaca mengingat dahulu apa yang telah diketahui atau menentukan apa yang ingin diketahui dengan melakukan pembacaan (bahan yang telah dipilih). Teknik pembacaan akan membiasakan pelajar mengaitkan pengetahuan yang telah dipelajari dengan apa yang dibaca dan menentukan apa yang telah diperoleh dari pembacaannya.

Menurut Tierney seperti yang disitasi oleh Lance dan Barton (2009), ada tiga tahapan besar dalam teknik KWL yaitu: (1) tahap K (What I Know "apa yang saya pelajari”). Siswa diajak bercurah pendapat tentang tema, topik, judul, dan ilustrasi atau gambar-gambar yang terdapat dalam teks. Dengan aktivitas itu skemata pembaca menjadi aktif kembali, sehingga pemahaman akan lebih mudah dicapai oleh pembaca. Disamping itu, guru juga mengaktifkan skemata siswa tentang bahasa yang digunakan dalam teks.

Pengaktifan skemata bahasa dilakukan dengan mengangkat berbagai istilah, kata, frase, atau kalimat yang merupakan kunci dalam memahami isi yang terkandung dalam teks bacaan. Kegiatan tahap $\mathrm{K}$ ini akan menghasilkan sebuah jaring laba-laba. Isi jaring laba-laba ini mencakup tema, topik-topik, subsubtopik, serta beberapa detail dari subtopik yangdipandang perlu. Curah pendapat tidak perlu sampai pada semua detail dari setiap subtopik yang ada, karena akan terlalu banyak menyita waktu. Guru perlu terlebih dahulu merancangnya secara lengkap dan luas sebelum melaksanakan kegiatan pembelajaran, (2) tahap $\mathrm{W}$ (What I Want to learn "apa yang ingin saya pelajari"). Guru mengidentifikasi berbagai hal yang bagi siswa merupakan hal yang menarik, kurang dipahami, meragukan, atau menjadi silang pendapat. Guru menyusun sejumlah pertanyaan yang merupakan tujuan dari kegiatan siswa membaca. Akan lebih praktis apabila sejumlah pertanyaan tersebut disusun sebelum pembelajaran, karena apabila disusun dalam pembelajaran akan menyita waktu yang lebih banyak. Apabila ada tambahan pertanyaan, guru tinggal menambahkannya. Fase ini membimbing aktivitas membaca menjadi aktivitas yang bertujuan dan pikiran siswa akan lebih terfokus pada hal-hal yang hendak dicarinya dalam teks.

Tanpa adanya tujuan yang hendak dicari, pikiran siswa akan sulit merekam informasi-informasi penting yang terdapat dalam teks. Tahap ini dapat juga dikatakan sebagai tahap untuk meningkatkan keingintahuan siswa terhadap informasiinformasi yang akan disampaikan penulis melalui teks, (3) tahap L (What I Learned "apa yang telah saya pelajari"). Siswa dipersilakan membaca teks yang telah ditentukan sambil berpedoman pada sejumlah pertanyaan yang telah diterimanya. Pada tahap akhir L, mungkin saja ada pertanyaan-pertanyaan yang belum terjawab. Pada tahap ini pembaca didorong untuk menyelidiki lebih lanjut infomasi tersebut yang tidak terdapat di dalam teks.

DRTA adalah strategi mengajar yang membimbing siswa dalam membuat prediksi mengenai bacaan dan membaca untuk mengkonfirmasi ataupun membantah prediksi mereka. Strategi ini mendorong siswa menjadi aktif dan pembaca yang kritis dengan meningkatkan pemahaman mereka. Tujuan penggunaan strategi ini adalah untuk melatih siswa berkonsentrasi dan "berpikir keras" guna memahami isi bacaan secara serius (teacher vision, 2011). Tujuan strategi DRTA secara lebih rinci adalah sebagai berikut: (1) mendorong siswa untuk menjadi pembaca aktif dan berpikir, (2) merangsang atau mengaktifkan pengetahuan siswa, (3) mengajak siswa memonitor pemahaman mereka atas bacaan yang mereka baca, (4) membantu menguatkan kemampuan membaca dan ketrampilan berpikir kritis siswa. Strategi DRTA dapat digunakan sebelum membaca, selama membaca dan setelah membaca. DRTA dapat digunakan secara individu, kelompok kecil dan keseluruhan kelas yang sudah diatur.

Adapun langkah-langkah yang harus dilakukan guru dalam menggunakan DRTA adalah sebagai berikut: (1) menentukan teks bacaan yang akan digunakan dan sebelumnya tentukan poin-poin untuk siswa yang akan dibahas pada saat berhenti sementara dalam proses membaca, (2) memperkenalkan teks, tujuan dari DRTA, dan memberikan contoh bagaimana membuat prediksi. Catatan: Perhatikan tingkat pembacaan setiap siswa, dan bersiaplah untuk memberikan pertanyaan yang tepat, petunjuk dan dukungan yang diperlukan, (3) menggunakan garis besar untuk memandu prosedur, seperti:

$\mathrm{D}($ direct $)=$ Langsung. Guru secara langsung dan mengaktifkan siswa berpikir sebelum membaca suatu bagian dengan memindai judul, judul bab, ilustrasi, dan bahan lainnya. Guru harus menggunakan pertanyaanpertanyaan terbuka untuk siswa secara langsung, agar mereka membuat prediksi tentang isi atau perspektif dari teks (misalnya, 
"Dengan melihat judul ini, apa yang Anda pikirkan?

$\mathrm{R}$ (reading) $=$ Membaca. Siswa membaca sampai poin yang telah ditentukan untuk berhenti. Guru kemudian meminta siswa dengan pertanyaan-pertanyaan tentang informasi tertentu dan meminta mereka untuk mengevaluasi prediksi mereka dan memperbaikinya jika diperlukan. Proses ini harus dilanjutkan sampai siswa telah membaca setiap bagian dari teks tersebut.

$\mathrm{T}($ think $)=$ Berpikir. Pada akhir setiap bagian, siswa kembali melihat teks yang ada dan berpikir tentang prediksi mereka. Siswa harus memverifikasi atau memodifikasi prediksi mereka dengan menemukan pernyataanpernyataan pendukung dalam teks. Guru menanyakan hal-hal berikut: (a) apa pendapat
Anda tentang prediksi Anda sekarang?, (b) apa yang Anda temukan dalam teks untuk membuktikan prediksi Anda?, (c) apa yang Anda baca dalam teks yang membuat Anda mengubah prediksi anda?

Langkah-langkah pelaksanaan strategi DRTA mengadopsi salah satu model pembelajaran the information processing family (model pemrosesan informasi) yang modelmodel pembelajarannya bertujuan untuk meningkatkan kemampuan siswa mencari dan menguasai informasi dan mengorganisisr, membangun dan membuktikan prediksinya serta mempraktekan hasil prediksinya melalui tulisan atau bacaan bebas. Model pembelajaran pemahaman bacaan DRTA menurut Melvita (2009;54-55) dapat digambarkan pada Tabel 3. berikut ini:

Tabel 3. Deskripsi Model Pembelajaran Pemahaman Bacaan DRTA

\begin{tabular}{|c|l|}
\hline \multicolumn{1}{|c|}{ Urutan } & \multicolumn{1}{|c|}{ Deskripsi Kegiatan } \\
\hline $\begin{array}{c}\text { 1.Orientasi/ } \\
\text { Konfrontasi } \\
\text { Masalah }\end{array}$ & $\begin{array}{l}\text { Siswa dimotivasi untuk memahami bacaan berdasarkan petunjuk judul. } \\
\text { Siswa diarahkan untuk mengobservasi topik bacaan yang hendak } \\
\text { dipelajari berdasarkan petunjuk judul dan pengalaman atau pengetahuan } \\
\text { sebelumnya. }\end{array}$ \\
\hline $\begin{array}{c}\text { 2.Memperjelas } \\
\text { Ungkapan Ide }\end{array}$ & $\begin{array}{l}\text { Siswa dimotivasi untuk memahami bacaan berdasarkan petunjuk gambar } \\
\text { atau kata-kata kunci untuk lebih memperjelas topik bacaan. }\end{array}$ \\
\hline $\begin{array}{c}\text { 3.Mengumpulkan } \\
\text { Informasi dan } \\
\text { Menguji Ide }\end{array}$ & $\begin{array}{l}\text { Siswa dimotivasi untuk memahami tujuan dan manfaat dengan cara } \\
\text { memprediksinya berdasarkan informasi atau ide yang telah diperolehnya } \\
\text { baik dari pengalaman sebelumnya atau dari urutan kegiatan sebelumnya. } \\
\text { Siswa memahami bacaan dengan menemukan ide-ide pokok, menentukan } \\
\text { jenis teks berdasarkan penandanya. }\end{array}$ \\
\hline $\begin{array}{c}\text { 4.Mengorganisir } \\
\text { dan }\end{array}$ & $\begin{array}{l}\text { Siswa mengorganisir informasi yang telah diperoleh untuk memahami } \\
\text { keseluruhan bacaan, menemukan ide pokok dan menentukan jenis teks } \\
\text { anformulasik } \\
\text { an Penjelasan }\end{array}$ \\
$\begin{array}{l}\text { Siswa memformulasikan penjelasan atau informasi yang telah } \\
\text { diperolehnya dengan memaparkan prediksinya dan prediksi temannya } \\
\text { sehingga membentuk informasi baru. }\end{array}$ \\
\hline $\begin{array}{l}\text { Review } \\
\text { Revisi }\end{array}$ & $\begin{array}{l}\text { Siswa menganalisis prediksinya, mengulang prediksi dari judul, gambar } \\
\text { dan kata kunci serta membaca. Dengan menganalisis kemudian mereview } \\
\text { dan merevisi siswa dapat mengurangi atau menambahkan ataupun } \\
\text { mengganti berbagai kemungkinan prediksi baru yang lebih sesuai. }\end{array}$ \\
\hline
\end{tabular}

Sebagaimana siswa-siswa mempunyai kepribadian yang berbeda-beda, mereka juga mempunyai cara belajar yang berbeda (Slavin, 2008:168). Dengan memahami gaya belajar, strategi yang tepat dapat dipelajari dan ketrampilan belajar juga dapat ditingkatkan. Gaya belajar merupakan kecendrungan untuk mengadaptasi suatu strategi belajar tertentu dengan mencari dan mencoba secara aktif sehingga pada akhirnya individu mendapatkan satu pendekatan belajar yang sesuai dengan tuntutan belajar. Sedangkan menurut De Porter dan Hemacki dalam Sukadji dan Singgih, Evita (2001:96), gaya belajar adalah kombinasi dari cara seseorang menyerap dan kemudian mengatur serta mengolah informasi. Gaya belajar merupakan kunci untuk mengembangkan kinerja dalam pekerjaan, di bidang akademik dan dalam situasi-situasi antar pribadi. Jika siswa hanya diajar dengan metode standar, sedikit saja yang dapat dipahami dari apa yang diberikan dalam proses pembelajaran. 
De Porter dan Hemacki seperti yang disitasi oleh Sukadji dan Singgih (2001:98), berikut ini memberikan ciri-ciri perilaku dan ungkapan- ungkapan yang menunjukkan dominasi belajar seseorang menurut gaya belajar visual, auditori dan kinestetik:

Tabel 4. Ciri-ciri Gaya Belajar Visual, Auditori dan Kinestetik

\begin{tabular}{|c|c|c|}
\hline Visual & Auditori & Kinestetik \\
\hline Rapi dan teratur. & & $\begin{array}{l}\text { Tidak dapat duduk diam } \\
\text { untuk waktu lama. }\end{array}$ \\
\hline Berbicara dengan cepat. & & Berbicara dengan perlahan. \\
\hline $\begin{array}{l}\text { Perencana dan pengatur jangka } \\
\text { panjang yang baik. }\end{array}$ & & $\begin{array}{l}\text { Selalu berorientasi pada fisik } \\
\text { dan banyak bergerak. }\end{array}$ \\
\hline Teliti dan detail. & $\begin{array}{l}\text { Bagus dalam mengingat } \\
\text { fakta. }\end{array}$ & $\begin{array}{l}\text { Berdiri dekat ketika } \\
\text { berbicara dengan orang. }\end{array}$ \\
\hline $\begin{array}{l}\text { Mementingkan penampilan, baik } \\
\text { dalam hal pakaian maupun } \\
\text { presentasi. }\end{array}$ & Selera, yang penting label. & $\begin{array}{l}\text { Selera nyaman dan rasa. } \\
\text { Bahan lebih penting daripada } \\
\text { gaya. }\end{array}$ \\
\hline $\begin{array}{l}\text { Pengeja yang baik dan dapat } \\
\text { melihat kata-kata yang sebenarnya } \\
\text { dalam pikiran mereka. }\end{array}$ & $\begin{array}{l}\text { Lebih pandai mengeja } \\
\text { dengan keras daripada } \\
\text { menuliskannya. }\end{array}$ & $\begin{array}{l}\text { Menggunakan jari sebagai } \\
\text { petunjuk ketika membaca. }\end{array}$ \\
\hline $\begin{array}{l}\text { Mengingat apa yang dilihat, } \\
\text { daripada yang didengar. }\end{array}$ & $\begin{array}{l}\text { Mengingat apa yang } \\
\text { didiskusikan daripada yang } \\
\text { dilihat. }\end{array}$ & $\begin{array}{l}\text { Belajar melalui manipulasi } \\
\text { dan praktik. }\end{array}$ \\
\hline dengan a & $\begin{array}{l}\text { Belajar dengan } \\
\text { mendengarkan. }\end{array}$ & $\begin{array}{l}\text { Banyak menggunakan isyarat } \\
\text { tubuh. }\end{array}$ \\
\hline tidak terganggu oleh & $\begin{array}{l}\text { terganggu oleh } \\
\text { an. }\end{array}$ & $\begin{array}{l}\text { Menyentuh orang untuk } \\
\text { mendapatkan perhatian } \\
\text { mereka. }\end{array}$ \\
\hline $\begin{array}{l}\text { Mempunyai masalah untuk } \\
\text { mengingat instruksi verbal kecuali } \\
\text { ditulis dan sering kali minta } \\
\text { bantuan orang lain untuk } \\
\text { mengulanginya. }\end{array}$ & $\begin{array}{l}\text { Mempunyai masalah dengan } \\
\text { pekerjaan-pekerjaan yang } \\
\text { melibatkan visualisasi, } \\
\text { seperti memotong bagian- } \\
\text { bagian hingga sesuai satu } \\
\text { sama lain. }\end{array}$ & $\begin{array}{l}\text { Tidak dapat mengingat } \\
\text { geografi kecuali jika } \\
\text { memang telah pernah berada } \\
\text { di tempat itu. }\end{array}$ \\
\hline Pemba & $\begin{array}{l}\text { auan lisan } \\
\text { aca komik }\end{array}$ & $\begin{array}{l}\text { Mempunyai } \\
\text { awal otot ya }\end{array}$ \\
\hline Ka memoaca aaripada & $\begin{array}{l}\text { a dengan } \\
\text { ngarkan. }\end{array}$ & $\begin{array}{l}\text { Menghafal dengan cara } \\
\text { berjalan dan melihat. }\end{array}$ \\
\hline $\begin{array}{l}\text { Membutuhkan pandangan dan } \\
\text { tujuan yang menyeluruh da } \\
\text { bersikap waspada sebelum secara } \\
\text { mental merasa pasti tentang suatu } \\
\text { masalah atau proyek. }\end{array}$ & $\begin{array}{l}\text { Suka berbicara, suka } \\
\text { berdiskusi dan menjelaskan } \\
\text { sesuatu panjang lebar. }\end{array}$ & $\begin{array}{l}\text { Menyukai buku-buku yang } \\
\text { berorientasi pada suatu } \\
\text { rancangan yang } \\
\text { mencerminkan aksi dengan } \\
\text { gerakan tubuh saat membaca. }\end{array}$ \\
\hline $\begin{array}{l}\text { Mencoret-coret tanpa arti selama } \\
\text { berbicara ditelepon dan dalam } \\
\text { rapat. }\end{array}$ & $\begin{array}{l}\text { Merasa kesulitan untuk } \\
\text { menulis tetapi hebat dalam } \\
\text { bercerita. }\end{array}$ & $\begin{array}{l}\text { Kemungkinan tulisannya } \\
\text { jelek. }\end{array}$ \\
\hline $\begin{array}{l}\text { Lupa menyampaikan pesan verbal } \\
\text { kepada orang lain, sering } \\
\text { menjawab pertanyaan dengan } \\
\text { jawaban singkat ya atau tidak. }\end{array}$ & $\begin{array}{l}\text { Berbicara dengan irama yang } \\
\text { terpola. }\end{array}$ & $\begin{array}{l}\text { Menggunakan kata-kata yang } \\
\text { mengandung aksi. }\end{array}$ \\
\hline $\begin{array}{l}\text { Lebih suka melakukan demonstrasi } \\
\text { daripada berpidato, lebih suka seni } \\
\text { rupa daripada musik. }\end{array}$ & $\begin{array}{l}\text { Lebih suka musik daripada } \\
\text { seni rupa. }\end{array}$ & $\begin{array}{l}\text { Ingin melakukan segala } \\
\text { sesuatu. }\end{array}$ \\
\hline Seringkali mengetahui apa yang & Biasanya pembicara yang & Menanggapi perhatian fisik. \\
\hline
\end{tabular}




\begin{tabular}{|l|l|l|}
\hline \multicolumn{1}{|c|}{ Visual } & \multicolumn{1}{c|}{ Auditori } & \multicolumn{1}{c|}{ Kinestetik } \\
\hline $\begin{array}{l}\text { harus dikatakan tetapi tidak pandai } \\
\text { memilih kata-kata. }\end{array}$ & fasih. & $\begin{array}{l}\text { Dapat mengulangi kembali } \\
\text { dan menirukan nada, birama } \\
\text { dan warna suara. }\end{array}$ \\
\hline $\begin{array}{l}\text { Kadang-kadang kehilangan } \\
\text { konsentrasi ketika merasa ingin } \\
\text { memperhatikan sesuatu yang } \\
\text { menarik. }\end{array}$ & $\begin{array}{l}\text { Menyukai permainan yang } \\
\text { menyibukkan. }\end{array}$ \\
\hline
\end{tabular}

Rumusan masalah penelitian ini adalah: (1) Apakah hasil belajar Bahasa Indonesia dalam pembelajaran pemahaman bacaan antara siswa yang diajar dengan strategi pembelajaran pemahaman bacaan DRTA berbeda dari siswa yang diajar dengan strategi pembelajaran KWL?; (2) Apakah hasil belajar Bahasa Indonesia berbeda antara siswa yang memiliki kecendrungan gaya belajar visual, auditori dan kinestetik?; dan (3) Apakah ada interaksi antara strategi pembelajaran dan gaya belajar terhadap hasil belajar Bahasa Indonesia siswa SMP Dharma Pancasila Medan?

\section{METODE}

Penelitian ini dilaksanakan di SMP Dharma Pancasila Kota Medan Provinsi Sumatera Utara dan SMP Katolik Tri Sakti-1 Medan sebagai pembanding, baik untuk uji coba instrumen maupun pelaksanaan penelitian. Populasi penelitian ini adalah seluruh siswa SMP kelas VII di SMP Dharma Pancasila yang terdiri dari lima kelas dengan jumlah populasi siswa kelas VII adalah 184 siswa, serta SMP Katolik Tri Sakti-1 sebagai sekolah pembanding dengan jumlah populasi siswa kelas VII yang terdiri dari lima kelas sebesar 219 siswa. Jadi populasi siswa kelas VII dari kedua sekolah tersebut adalah sebesar 403 siswa.

Teknik penentuan sample menggunakan cluster sampling. Teknik ini dipilih karena yang disampling dari populasi adalah jumlah kelas dan bukan jumlah siswa dalam populasi. Sampel yang diambil terdiri dari dua kelompok yaitu satu kelompok kelas di SMP Dharma Pancasila akan dilakukan pembelajaran Bahasa Indonesia dengan menggunakan strategi pembelajaran DRTA dan satu kelas lainnya di SMP Trisakti sebagai sekolah pembanding yang dipilih untuk diterapkan pembelajaran Bahasa Indonesia dengan menggunakan strategi pembelajaran KWL.

Metode yang dipergunakan dalam penelitian ini adalah metode quasi-eksperimen. Desain penelitian yang digunakan dalam penelitian adalah ANAVA faktorial $2 \times 3$ sebagaimana terlihat pada tabel berikut :

Tabel 5. Matrik Rancangan Penelitian

\begin{tabular}{|c|c|c|}
\hline \multirow{2}{*}{$\begin{array}{c}\text { aaya Belajar } \\
\text { (B) }\end{array}$} & \multicolumn{2}{|c|}{ Strategi Pembelajaran (A) } \\
\cline { 2 - 3 } & DRTA (A1) & KWL (A2) \\
\hline Visual (B1) & A1B1 & A2B1 \\
\hline Auditori (B2) & A1B2 & A2B2 \\
\hline Kinestetik (B3) & A1B3 & A2B3 \\
\hline
\end{tabular}

Keterangan :

A1B1 = Hasil belajar siswa dengan gaya belajar visual yang diajar dengan strategi pembelajaran DRTA.

A1B2 = Hasil belajar siswa dengan gaya belajar auditori yang diajar dengan strategi pembelajaran DRTA.

A1B3 = Hasil belajar siswa dengan gaya belajar kinestetik yang diajar dengan strategi pembelajaran DRTA.

A2B1 = Hasil belajar siswa dengan gaya belajar visual yang diajar dengan strategi pembelajaran KWL.

A2B2 = Hasil belajar siswa dengan gaya belajar auditorial yang diajar dengan strategi pembelajaran KWL.

A2B3 = Hasil belajar siswa dengan gaya belajar kinestetik yang diajar dengan strategi pembelajaran KWL.

Teknik analisis data yang digunakan dalam penelitian ini adalah: (1) analisis deskriptif dan (2) analisis inferensial. Sebelum hipotesis, terlebih dahulu dilakukan uji persyaratan analisis yaitu (1) uji normalitas, dimaksudkan untuk mengetahui apakah data yang diteliti berdistribusi normal atau tidak, (2) uji homogenitas, dilakukan untuk melihat apakah data yang diperoleh memiliki variasi yang homogen atau tidak. Selanjutnya dalam pengujian hipotesis penelitian maka hipotesis statistik dapat dinyatakan sebagai berikut :

Hipotesis pertama :

Ho $: \mu \mathrm{SP}_{\mathrm{KWL}}=\mu \mathrm{SP}_{\mathrm{DRTA}}$

$\mathrm{Ha}: \mu \mathrm{SP}_{\mathrm{KWL}}>\mu \mathrm{SP}_{\mathrm{DRTA}}$

Hipotesis Kedua : 
Ho: $\mu \mathrm{GB}_{\mathrm{A}}=\mu \mathrm{GB}_{\mathrm{V}}=\mu \mathrm{GB}_{\mathrm{K}}$

$\mathrm{Ha}: \mu \mathrm{GB}_{\mathrm{A}}=\mu \mathrm{GB}_{\mathrm{V}} \neq \mu \mathrm{GB}_{\mathrm{K}}$

Hipotesis Ketiga : Ho : SP X GB $=0$

$\mathrm{Ha}: \mathrm{SP} X \mathrm{XB} \neq 0$

Setelah pengujian hipotesis dilakukan maka dilakukan pengujian uji lanjut. Jika $\mathrm{n}$ pada masing-masing sel berbeda jumlahnya maka dilakukan uji lanjut dengan uji Scheffe. jika $n$ pada masing-masing berjumlah sama maka dilakukan uji Tuckey.

\section{HASIL DAN PEMBAHASAN \\ Hasil}

Pengujian hipotesis penelitian dilakukan dengan menggunakan ANAVA 2x3 yang dapat dilihat pada Tabel 6 .

Tabel 6. Ringkasan Hasil Pengujian Hipotesis Penelitian dengan Menggunakan ANAVA

\begin{tabular}{|c|c|c|c|c|}
\hline \multicolumn{2}{|c|}{$\begin{array}{ll}\text { Gaya Belajar } & \text { Strategi }\end{array}$} & \multirow{2}{*}{$\begin{array}{c}\text { DRTA (A1) } \\
15 \\
\end{array}$} & \multirow{2}{*}{$\begin{array}{c}\text { KWL (A2) } \\
14 \\
\end{array}$} & \multirow{2}{*}{\begin{tabular}{r|} 
Total \\
29 \\
\end{tabular}} \\
\hline \multirow{5}{*}{ VISUAL (B1) } & $\mathrm{n}$ & & & \\
\hline & Sigma $\mathrm{x}$ & 392 & 322 & 714 \\
\hline & Sigma $X^{\wedge} 2$ & 10302 & 7462 & 17764 \\
\hline & rata2 & 26,13 & 23 & 24,57 \\
\hline & SD & 2,03 & 2,08 & 2,05 \\
\hline \multirow{5}{*}{ AUDITORI (B2) } & $\mathrm{n}$ & 12 & 15 & 27 \\
\hline & Sigma $x$ & 286 & 372 & 658 \\
\hline & Sigma $X^{\wedge} 2$ & 6866 & 9288 & 16154 \\
\hline & rata2 & 23,83 & 24,8 & 24,32 \\
\hline & SD & 2,12 & 2,11 & 2,12 \\
\hline \multirow{5}{*}{$\begin{array}{l}\text { KINESTETIK } \\
\text { (B3) }\end{array}$} & $\mathrm{n}$ & 13 & 11 & 24 \\
\hline & Sigma $\mathrm{x}$ & 303 & 246 & 549 \\
\hline & Sigma $X^{\wedge} 2$ & 7125 & 5546 & 12671 \\
\hline & rata2 & 23,31 & 22,36 & 22,84 \\
\hline & SD & 2,29 & 2,11 & 2,20 \\
\hline \multirow{5}{*}{ Total } & $\mathrm{n}$ & 40 & 40 & 80 \\
\hline & Sigma $\mathrm{x}$ & 981 & 940 & 1921 \\
\hline & Sigma $X^{\wedge} 2$ & 24293 & 22296 & 46589 \\
\hline & rata2 & 24,42 & 23,39 & 23,91 \\
\hline & SD & 2,15 & 2,10 & 2,12 \\
\hline
\end{tabular}

Perhitungan selengkapnya terdapat pada bagian lampiran penelitian ini. Adapun ringkasan hasil perhitungannya dapat dilihat pada Tabel 7. berikut ini :

Tabel 7. Ringkasan Hasil Perhitungan ANAVA Dua Jalur

\begin{tabular}{|l|c|c|c|c|c|c|}
\hline \multicolumn{1}{|c|}{ Sumber Variansi } & dk & JK & RJK & F $_{\text {hitung }}$ & F $_{\text {tabel 5\% }}$ & Keterangan \\
\hline Strategi Pembelajaran & 1 & 21,012 & 21,012 & 4,793 & 3,96 & Signifikan \\
\hline Kecendrungan Gaya Belajar & 1 & 45,238 & 45,238 & 10,32 & 3,96 & Signifikan \\
\hline Interaksi & 1 & 61,621 & 61,621 & 14,058 & 3,96 & Signifikan \\
\hline Antar Kelompok & 3 & 42,624 & & & & \\
\hline Dalam Kelompok & 76 & 4,383 & & & & \\
\hline Total & $\mathbf{7 9}$ & $\mathbf{4 6 0 , 9 8 7}$ & & & & \\
\hline
\end{tabular}


Dikarenakan terdapat interaksi antara strategi pembelajaran dan kecendrungan gaya belajar siswa dalam mempengaruhi hasil belajar kemampuan membaca bahasa Indonesia maka perlu dilakukan uji lanjutan yaitu dengan menggunakan uji Scheffe. Ringkasan uji Scheffe dapat dilihat pada Tabel 8.

Tabel 8. Ringkasan Hasil Pengujian Perhitungan Perbandingan Ganda (Uji Scheffe)

\begin{tabular}{|c|c|c|c|}
\hline Kelompok yang Dibandingkan & $\mathbf{F}_{\text {hitung }}$ & $\mathbf{F}_{\text {tabel }(\boldsymbol{a}=\mathbf{5} \%)}$ & Keterangan \\
\hline$\mu \mathrm{A}_{1} \mathrm{~B}_{1}$ dengan $\mu \mathrm{A}_{2} \mathrm{~B}_{1}$ & 5,17 & 2,72 & Signifikan \\
\hline$\mu \mathrm{A}_{1} \mathrm{~B}_{1}$ dengan $\mu \mathrm{A}_{2} \mathrm{~B}_{2}$ & 2,28 & 2,72 & Tidak Signifikan \\
\hline$\mu \mathrm{A}_{1} \mathrm{~B}_{1}$ dengan $\mu \mathrm{A}_{2} \mathrm{~B}_{3}$ & 5,43 & 2,72 & Signifikan \\
\hline$\mu \mathrm{A}_{1} \mathrm{~B}_{1}$ dengan $\mu \mathrm{A}_{1} \mathrm{~B}_{2}$ & 3,49 & 2,72 & Signifikan \\
\hline$\mu \mathrm{A}_{1} \mathrm{~B}_{1}$ dengan $\mu \mathrm{A}_{1} \mathrm{~B}_{3}$ & 4,48 & 2,72 & Signifikan \\
\hline$\mu \mathrm{A}_{2} \mathrm{~B}_{1}$ dengan $\mu \mathrm{A}_{2} \mathrm{~B}_{2}$ & 2,97 & 2,72 & Signifikan \\
\hline$\mu \mathrm{A}_{2} \mathrm{~B}_{1}$ dengan $\mu \mathrm{A}_{2} \mathrm{~B}_{3}$ & 0,89 & 2,72 & Tidak Signifikan \\
\hline$\mu \mathrm{A}_{2} \mathrm{~B}_{1}$ dengan $\mu \mathrm{A}_{1} \mathrm{~B}_{2}$ & 1,22 & 2,72 & Tidak Signifikan \\
\hline$\mu \mathrm{A}_{2} \mathrm{~B}_{1}$ dengan $\mu \mathrm{A}_{1} \mathrm{~B}_{3}$ & 2,19 & 2,72 & Tidak Signifikan \\
\hline$\mu \mathrm{A}_{1} \mathrm{~B}_{2}$ dengan $\mu \mathrm{A}_{2} \mathrm{~B}_{2}$ & 1,47 & 2,72 & Tidak Signifikan \\
\hline$\mu \mathrm{A}_{1} \mathrm{~B}_{2}$ dengan $\mu \mathrm{A}_{2} \mathrm{~B}_{3}$ & 1,92 & 2,72 & Tidak Signifikan \\
\hline$\mu \mathrm{A}_{1} \mathrm{~B}_{3}$ dengan $\mu \mathrm{A}_{2} \mathrm{~B}_{2}$ & 2,37 & 2,72 & Tidak Signifikan \\
\hline$\mu \mathrm{A}_{1} \mathrm{~B}_{3}$ dengan $\mu \mathrm{A}_{2} \mathrm{~B}_{3}$ & 2,80 & 2,72 & Signifikan \\
\hline
\end{tabular}

Interaksi strategi pembelajaran dan kecendrungan gaya belajar siswa dapat dilihat pada Gambar interaksi berikut:

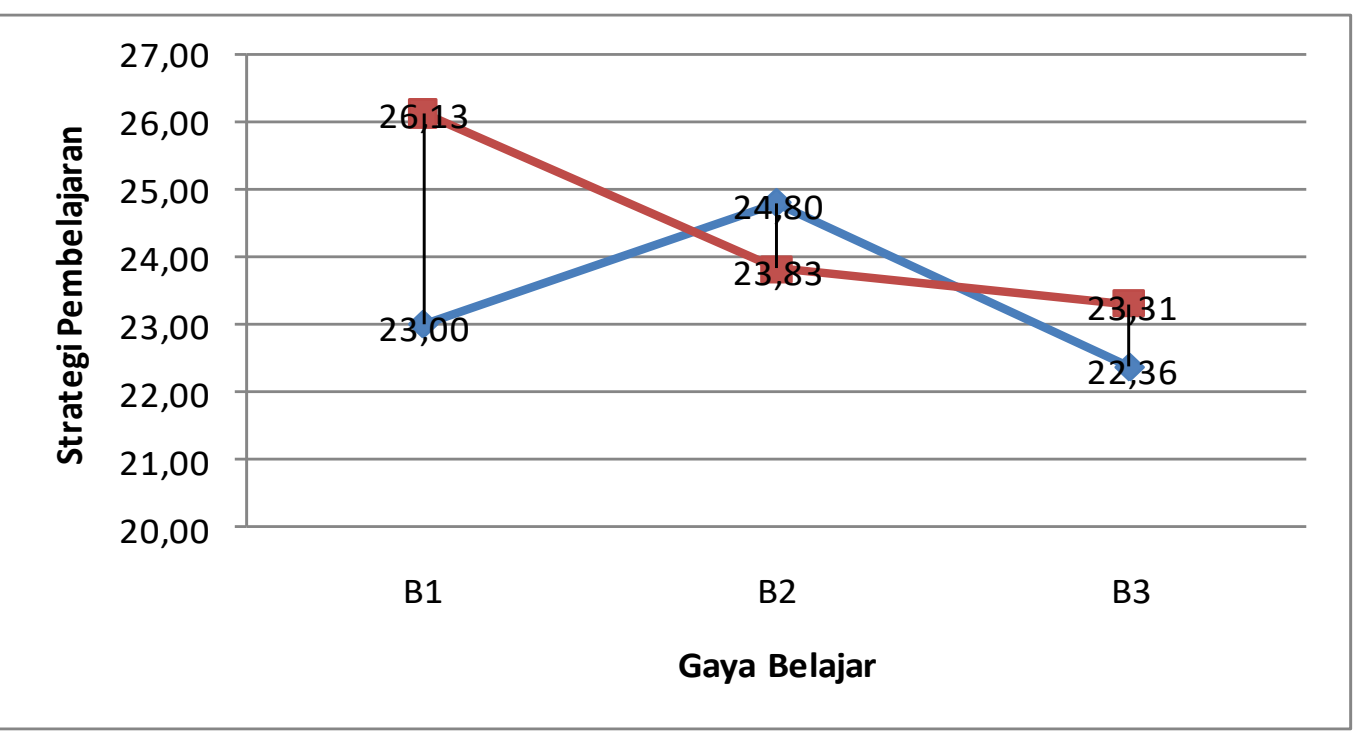

\section{Pembahasan}

Pembelajaran dengan menggunakan strategi pembelajaran DRTA mengarahkan siswa berpikir, memberi kesempatan kepada siswa untuk membuat prediksi bacaan terlebih dahulu berdasarkan bentuk teks (pendahuluan, ringkasan atau judul) yang mengarahkan siswa memperoleh tujuan dan memotivasi siswa dalam memahami bacaan. Seperti yang dikemukakan oleh Piaget yang disitasi oleh Budiningsih (2005:39), salah satu tahap perkembangan anak menurut kognitifnya adalah tahap operasional formal (umur 11/12-18 tahun), pada periode ini setingkat usia siswa sekolah menengah pertama. Ciri pokok perkembangan pada tahap ini adalah anak sudah mampu berpikir abstrak dan logis dengan menggunakan pola berpikir "kemungkinan atau membuat prediksi". Berdasarkan observasi di lapangan, guru seringkali mengabaikan salah satu langkah penting dalam pelajaran bahasa yaitu bagaimana menarik perhatian siswa dengan cara memaparkan manfaat informasi yang ada di dalam teks yang dibacanya sehingga informasi tersebut dapat lebih bermanfaat dalam kehidupan sehari-hari siswa. 
Strategi KWL yang juga melibatkan latar belakang pengetahuan siswa berfokus pada apa yang diketahui dan yang diinginkan oleh siswa dari bacaan atau tema yang telah dipersiapkan oleh guru namun kegiatan pembelajaran pada strategi KWL membuat siswa kurang memahami manfaat ataupun tujuan dari memahami bacaan ataupun tematema tertentu, terutama tema yang tidak sesuai dengan minat siswa. Kenyataan yang dihadapi dalam penerapan strategi DRTA sejalan dengan temuan dalam penelitian ini, yaitu menguatkan hipotesis bahwa hasil belajar kemampuan membaca bahasa Indonesia siswa yang dibelajarkan dengan menggunakan strategi DRTA lebih tinggi secara signifikan dari hasil belajar siswa yang dibelajarkan dengan menggunakan strategi KWL. Keunggulan dari strategi DRTA yang dipaparkan dalam kerangka berpikir terbukti secara empiris di lapangan, sehingga hasil ini telah menguatkan bahwa dengan strategi DRTA hasil belajar kemampuan membaca bahasa Indonesia siswa akan lebih baik.

Gaya belajar visual yaitu belajar dengan cara melihat. Mereka lebih muda mempelajari dengan membaca buku dan catatan yang diberikan secara jelas dan rapi. Bila belajar sendiri di rumah, maka membaca adalah cara yang paling tepat. Jika mereka tidak memiliki gambar atau alat bantu visual apapun untuk dilihat, maka sebaiknya mereka diberi penjelasan secara deskriptif agar mereka memiliki bayangan yang jelas tentang materi yang sedang dibicarakan. Menurut Soedarso (2005:19), kegiatan membaca dilakukan bersama-sama oleh mata dan otak. Mata bekerja seperti kamera, yaitu memotret. Hsilnya, film negatif. Selanjutnya, proses dilakukan di otak, hasilnya gambar positif. Mata melihat dan otak menginterpretasikan saat itu juga sehingga apa yang dilihat, itulah yang didapat. Otak menyerap apa yang dilihat mata.Oleh karena itu, melihat adalah mengerti.

Gaya belajar auditori belajar dengan cara mendengar, berbicara pada diri sendiri dan juga mendiskusikan ide dan pemikiran mereka pada orang lain. Untuk memahami materi dengan lebih baik, mereka biasanya membaca dengan suara keras atau suara pelan, cukup didengar diri sendiri atau membaca saja dalam hati. Mereka mungkin akan sering berhenti dan menanyakan beberapa pertanyaan pada diri sendiri tentang materi yang sedang mereka baca. Menurut Soedarso (2005:49-50), membaca merupakan aktivitas aktif, memberi tanggapan terhadap arti apa yang dibaca. Makin kurang aktivitas verbalisasi, makin cepat tanggapan itu. Informasi yang diserap dalam membaca sama dengan apa yang diserap waktu mendengarkan. Bila membaca sumber informasinya adalah kata yang dicetak, dalam mendengarkan sumeber informasinya adalah ucapan. Kesan yang diperoleh oleh mata atau telinga diantar ke otak dan pembaca atau pendengar mengerti informasi yang diemban oleh kata atau ucapan. Apabila siswa akrab arti kata bacaan atau ucapan maka siswa akan cepat mengerti.

Gaya belajar kinestetis belajar dengan menggerakkan otot-otot tubuh mereka dan secara aktif terlibat dalam suatu kegiatan seperti roleplay, simulasi, eksperimen, usaha eksplorasi dan gerakan-gerakan tertentu atau berpartisipasi dalam sebuah aktifitas dalam kehidupan nyata mereka. Mereka mungkin lebih mudah belajar sambil bersepeda atau mondar-mandir di seputar ruangan. Bermain, simulasi, role play dan kompetisi akan mempercepat proses belajar mereka.

Perbedaan gaya belajar antar satu individu dengan individu lainnya terkadang membuat guru kesulitan mengakomodir setiap gaya belajar siswanya secara satu persatu, dengan demikian guru dianjurkan mendesain pembelajaran yang dapat mengorganisir kegiatan pembelajaran berbeda-beda di waktu yang berbeda dengan gaya belajar yang berbeda. Jika guru mengorganisir kegiatan membaca dapat meminta siswa membaca keras-keras sehingga dapat mengakomodir kelompok siswa yang mempunyai kecendrungan gaya belajar auditori. Jika guru mengorganisir kegiatan memprediksi makna bacaan, guru dapat meminta siswa memberi warna atau menggaris bawahi kata atau kalimat tertentu yang dianggap merupakan ide pokok dari bacaan sehingga dapat mengakomodir kelompok siswa yang mempunyai kecendrungan gaya belajar visual. Selain itu, guru juga dapat meminta siswa menulis pada lembar kerja siswa atau meminta siswa maju ke depan untuk menulis di papan tulis mengenai ide pokok dari teks bacaan sehingga dapat mengakomodir kelompok siswa yang mempunyai kecendrungan gaya belajar kinestetis.

Bagi siswa yang memiliki kecendrungan gaya belajar visual, membaca merupakan kegiatan yang menolong mereka menerima dan memasukkan informasi dengan cara melihat sehingga diharapkan dapat terakomodir dengan strategi pembelajaran DRTA atau dengan strategi pembelajaran KWL. 
Hal ini terbukti secara empiris di lapangan bahwa hasil belajar bahasa Indonesia siswa yang memiliki kecendrungan gaya belajar visual dan yang diajar dengan strategi pembelajaran DRTA maupun strategi pembelajaran KWL terdapat perbedaan.

Jika siswa yang memiliki kecendrungan gaya belajar visual lebih terakomodir gaya belajarnya dengan membaca, maka siswa yang memiliki kecendrungan gaya belajar auditori lebih terakomodir gaya belajarnya dengan kegiatan mendiskusikan apa yang dibacanya dan memahami apa yang mereka dengar dan apa yang mereka katakan. Siswa yang memiliki kecendrungan gaya belajar kinestetik lebih terakomodir menerima informasi dengan kegiatan gerakan.

Dari hasil analisis data secara keseluruhan diperoleh rata-rata hasil belajar siswa yang memiliki kecendrungan gaya belajar visual yang diajar dengan strategi DRTA adalah 26,13 dan siswa yang memiliki kecendrungan gaya belajar auditori adalah 23,83, sedangkan siswa yang memiliki kecendrungan gaya belajar kinestetik adalah 23,30. Hal ini berindikasi bahwa siswa yang memiliki kecendrungan gaya belajar visual secara rata-rata mempunyai hasil belajar bahasa Indonesia lebih baik dibandingkan dengan siswa yang memilliki gaya belajar auditori dan kinestetik.

Hasil analisis data secara keseluruhan siswa yang diajar dengan strategi KWL ratarata hasil belajar siswa yang memiliki kecendrungan gaya belajar visual adalah 23 dan siswa yang memiliki kecendrungan gaya belajar auditori adalah 24,8, sedangkan siswa yang memiliki kecendrungan gaya belajar kinestetik adalah 22,36. Hal ini berindikasi bahwa siswa yang memiliki kecendrungan gaya belajar auditori secara rata-rata mempunyai hasil belajar bahasa Indonesia lebih baik dibandingkan dengan siswa yang memiliki kecendrungan gaya belajar visual dan kinestetik.

Dengan demikian dugaan bahwa hasil belajar visual, auditori dan kinestetik memiliki perbedaan hasil belajar. Hal ini mendukung teori yang diungkapkan oleh Slavin dimana siswa-siswa mempunyai kepribadian yang berbeda-beda, mereka juga mempunyai cara belajar yang berbeda (Slavin, 2008:168). Dengan memahami gaya belajar, strategi yang tepat dapat dipelajari dan ketrampilan belajar juga dapat ditingkatkan.

Dua faktor yang perlu dipertimbangkan dalam usaha meningkatkan hasil belajar siswa adalah strategi pembelajaran dan kecendrungan gaya belajar siswa. Untuk dapat memahami bacaan berbahasa Indonesia, diperlukan kegiatan yang yang dapat mengakomodir penerimaan informasi baru, menyimpan dan memanggil kembali informasi yang pernah siswa peroleh sebelumnya. Guru perlu memahami peserta didiknya, gaya belajar peserta didik perlu diketahui untuk memudahkan guru dalam memahami pebelajar dan menentukan strategi yang akan digunakan untuk mengajar dalam proses pembelajaran. Strategi yang akan dipilih perlu disesuaikan dengan juga dengan tujuan yang akan dicapai dari mata pelajaran yang akan diajarkan dimana, dalam hal ini adalah mata pelajaran bahasa Indonesia, khususnya dalam kompetensi dasar membaca.

Pengetahuan tentang gaya belajar dapat membantu para guru untuk menciptakan lingkungan belajar yang bersifat multi indrawi, yang melayani sebaik mungkin kebutuhan gaya belajar setiap siswa. Dengan memanfaatkan konsep keragaman dan menerima gaya yang berbeda, para guru akan lebih efektif dalam menentukan strategi-strategi pembelajaran dan siswa akan menjadi lebih percaya diri dan lebih puas dengan kemampuan belajar mereka. Dari hal ini diharapkan proses pembelajaran akan menjadi lebih efektif.

Bagi para guru, memahami proses belajar yang terjadi di dalam otak para siswa, menerima keragaman siswa dan kebutuhankebutuhan belajar mereka yang berbeda akan mengarah pada praktik pengajaran yang lebih baik, yaitu penggunaan peralatan belajar yang baru dan teknik-teknik manajemen kelas yang baru. Bagi para siswa, ini berarti bahwa mengerti fungsi-fungsi otak dengan gaya belajarnya akan menambah percaya diri, meningkatkan prestasi, dan memperoleh keberhasilan belajar. Oleh karenanya, upaya guru dalam mengakomodasi keragaman gaya belajar para siswanya sangat membantu dalam proses tercapainya tujuan pembelajaran.

Pengetahuan mengenai gaya belajar dapat menjadi basis dalam interaksi siswa-guru dalam upaya memahami dan mendukung siswa menyangkut kebutuhan belajar siswa dan membantu mereka menjadi lebih fleksibel dalam belajar. Penyesuaian gaya belajar siswa dan gaya mengajar, manajemen kelas yang lebih baik, dan teknik-teknik pengajaran kreatif akan membantu semua siswa memunculkan potensi mereka dan meningkatkan prestasi. Pada praktiknya, proses bagaimana guru berkomunikasi dengan siswa juga sama 
pentingnya. Tidak dapat dipungkiri bahwa cara mereka saling berinteraksi memberi pengaruh yang cukup besar pada keberhasilan atau kegagalan proses belajar.

Bagi siswa yang memiliki kecendrungan gaya belajar visual, guru dapat menggunakan media papan tulis. Di sinilah semua informasi diberikan, fakta dibagikan, rumus digunakan, dan lain-lain. Bagi siswa yang memiliki kecendrungan gaya belajar auditori, perubahan nada suara guru lebih nyata dan guru berbicara dengan irama yang alami. Sedangkan bagi siswa yang memiliki kecendrungan gaya belajar kinestetik, guru dapat meminta siswa membentuk kelompok, pindah tempat duduk, berdiri dan menggeliat, dan lain-lain.

Bagi siswa yang memiliki gaya belajar visual, lebih mudah menggambarkan kata dan perasaan dengan melihat pesan informasi baik yang tertulis maupun tergambar. Bagi siswa yang memiliki kecenderungan gaya belajar auditori, akan lebih mudah menerima informasi dari kekuatan mendengar, lebih mudah mengekspresikan diri mereka melalui suara baik melalui komunikasi dengan diri sendiri maupun dengan orang lain. Bagi siswa yang memiliki gaya belajar kinestetik, akan lebih peka terhadap rasa atau emosi dan pada sensasi atau sentuhan dan gerakan, lebih suka pada terhadap aktivitas atau penanganan langsung.

\section{PENUTUP}

\section{Simpulan}

Pertama, secara keseluruhan hasil belajar kemampuan membaca Bahasa Indonesia siswa yang diajar dengan strategi pembelajaran DRTA lebih baik daripada hasil belajar kemampuan membaca bahasa Indonesia siswa yang diajar dengan strategi pembelajaran KWL.

Kedua, terdapat perbedaan hasil belajar kemampuan membaca bahasa Indonesia antara siswa yang memiliki kecendrungan gaya belajar visual, auditori dan kinestetik. Pada siswa yang memiliki kecendrungan gaya belajar visual terdapat perbedaan yang signifikan dengan siswa yang memiliki kecendrungan gaya belajar auditori terhadap hasil belajar kemampuan membaca bahasa Indonesianya. Kecendrungan gaya belajar visual dan auditori mempunyai hasil belajar kemampuan membaca bahasa Indonesia yang lebih baik dari siswa yang memiliki kecendrungan gaya belajar kinestetik.

Ketiga, terdapat interaksi antara strategi pembelajaran dan kecendrungan gaya belajar terhadap hasil belajar bahasa Indonesia. Hasil belajar bahasa Indonesia yang paling baik adalah pada siswa yang memiliki kecendrungan gaya belajar visual dan diajar dengan strategi pembelajaran DRTA. Hasil belajar bahasa Indonesia siswa yang diajar dengan strategi pembelajaran KWL dan memiliki kecendrungan gaya belajar auditori, visual dan kinestetik menunjukkan terdapat perbedaan yang signifikan dari ketiga kelompok tersebut. Dengan demikian siswa yang memiliki kecendrungan gaya belajar auditori lebih efektif diajarkan dengan strategi pembelajaran KWL. Hasil pengujian statistik membuktikan ada interaksi antara strategi pembelajaran dengan kecendrungan gaya belajar siswa. Dengan demikian dapat dikatakan bahwa hasil belajar bahasa Indonesia dipengaruhi oleh strategi pembelajaran dan kecendrungan gaya belajar siswa.

\section{Saran}

Kepada guru bahasa Indonesia Sekolah Menengah Pertama yang memiliki dominasi siswa dengan kecendrungan gaya belajar visual agar dapat menerapkan strategi pembelajaran DRTA, khususnya untuk kompetensi membaca.

Untuk mengetahui gaya belajar dirinya sendiri. Hal ini untuk menciptakan komunikasi yang baik antara guru dan siswa yang mungkin memiliki kecendrungan gaya belajar yang berbeda dan menghindari kecendrungan guru untuk memaksakan gaya belajarnya terhadap siswa yang memiliki kecendrungan gaya belajar yang berbeda dari guru.

Bagi kepala sekolah dan guru disarankan terus melatih diri dan memperkaya diri dalam meningkatkan pengetahuan mengenai strategi pembelajaran yang baik. Waktu untuk diskusi bagi kedua belah pihak perlu disediakan secara khusus.

Bagi pengelola lembaga pendidikan dan kepala sekolah perlu melakukan sosialisasi dan pelatihan mengenai strategi pembelajaran dan gaya belajar kepada guruguru agar pembelajaran dapat berjalan sesuai dengan tujuan yang diharapkan dan menjadi lebih baik.

Penelitian ini hanya melihat hasil belajar bahasa Indonesia dari aspek kognitif, disarankan kepada peneliti selanjutnya 
untuk dapat melihat hasil belajar bahasa Indonesia sampai pada aspek psikomotor.

\section{DAFTAR PUSTAKA}

Anderson, Lorin W and Krathwohl, David R. 2001. A Taxonomy for Learning, Teaching, and Assessing. New York: Longman.

Armstrong, Thomas. 1994. Multiple Intellegences in the Classroom. Virginia: Association for Supervision and Curriculum Development Alexandria.

Atwi, Suparman. 2001. Desain Instruksional. Jakarta: Pusat Antar Universitas untuk Peningkatan dan Pengembangan Aktivitas Instruksional Direktorat Jenderal Pendidikan tinggi Departemen Pendidikan Nasional.

Budiningsih, Asri C. 2005. Belajar dan Pembelajaran. Jakarta: Rineka Cipta.

Chandra, Agus. 2010. Pengembangan Kurikulum Bahasa Indonesia, (Online), (http://agus.blogchandra.com/pengemban gan-kurikulum-bahasa-indonesia/, diakses 17 Januari 2011).

Conner, Jennifer. 2006. Instructional Reading Strategy: KWL (Know, want to Know, Learned) (online), (http://www.indiana .edu/ 1517/KWL.htm, diakses 20 Januari 2011).

Hamalik, Oemar. 2004. Proses Belajar Mengajar. Jakarta: Bumi Aksara.

Hamid, Abdul. 2009. Teori Belajar dan Pembelajaran. Edisi kedua. Medan: FR Dongoran.

Kurniawan, Heru. 2009. Sastra Anak dalam Kajian Strukturalisme, Sosiologi, Semiotika, hingga Penulisan Kreatif. Yogyakarta: Graha Ilmu.

Linksman, Ricki. 2004. Cara Belajar Cepat. Semarang: Effhar dan Dahara Prize.
Maisah dan Yamin Martinis, 2009. Manajemen Pembelajaran Kelas (Strategi Meningkatkan Mutu Pembelajaran). Jakarta: Gaung Persada Press.

McNeil, John D. 1992. Reading Comprehension, New Directions for Classroom Practise. Third Edition. New York: Harper Collins publishers.

Melvita, Santi. 2009. Pengaruh Strategi Pembelajaran dan Gaya Belajar Terhadap Hasil Belajar Bahasa Ingris di SMA Negeri 4 Banda Aceh. Medan: Program Pasca Sarjana Universitas Negeri Medan.

Muhfida. 2010. Pengarih Penggunaan Bahan Ajar dan Gaya Belajar Terhadap Hasil Belajar. (http://muhfida.com/gayabelajar/, diakses 16 September 2010).

Oka, I Gusti Ngurah dan Muslich, Masnur. 2010. Perencanan Bahasa pada Era Globalisasi. Jakarta: Bumi Aksara.

Santrock, John W. 2007. Psikologi Pendidikan. Edisi Kedua. Jakarta: Kencana Prenada Media Group.

Slavin, Robert E. 2008. Psikologi Pendidikan Teori dan Praktek. Edisi Kedelapan. Jakarta: PT Indeks.

Soedarso. 2005. Speed Reading. Sistem Membaca Cepat dan Efektif. Jakarta: PT Gramedia Pustaka Utama.

Sudijono, Anas. 2009. Pengantar Evaluasi Pendidikan. PT Raja Grafindo Persada. Jakarta.

Sudjana, Nana. 2005. Penilaian Hasil Proses Belajar Mengajar. Bandung: PT Remaja Rosdakarya.

Unimed, Tim Pascasarjana. 2010. Pedoman Administrasi dan Penulisan Tesis dan Disertasi. Medan: Program Pasca Sarjana Universitas Negeri Medan.

Willis, Judy. 2010. Strategi Pembelajaran Efektif Berbasis Riset Otak. Yogyakarta: Mitra Media. 